\title{
Habitat selection and 3D space use partitioning of resident juvenile hawksbill sea turtles in a small Caribbean bay
}

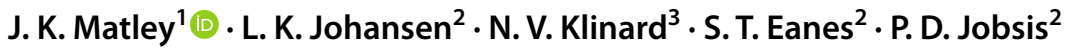

Received: 24 November 2020 / Accepted: 27 May 2021 / Published online: 6 July 2021

(c) The Author(s) 2021

\begin{abstract}
Understanding how aquatic animals select and partition resources provides relevant information about community dynamics that can be used to help manage conservation efforts. The critically endangered hawksbill sea turtle (Eretmochelys imbricata) spends an extended part of its juvenile development in coastal waters. A strong proclivity to remain resident in small areas, often in high density, raises questions about how juveniles partition resources including selection of habitat and spatial overlap among conspecifics. Using between 36 and 41 acoustic receivers in the $1.5 \mathrm{~km}^{2}$ study site, this study quantified day-and-night habitat selection, as well as 2D and 3D space use of 23 juvenile hawksbills within two adjacent Caribbean foraging grounds-Brewers Bay and Hawksbill Cove, St. Thomas, US Virgin Islands-between 2015 and 2018. We found that coral reef, rock, and the artificial dolosse forming an airport runway, were the most strongly selected habitats based on resource selection indices. Individual activity spaces in 2D and 3D were both larger during the day compared to night, although the same parts of the bay were used by each individual during both periods. The 3D approach also showed deeper space use during the day. Weekly comparisons of activity space between individuals showed limited overlap (mean 95\% UD overlap; day: 0.15 (2D) and 0.07 (3D), night: 0.11 (2D) and 0.03 (3D)), suggesting some degree of resource partitioning or territoriality. Results from this study provide relevant space use information for resource management of juvenile hawksbills, in which many populations are facing habitat degradation and population declines.
\end{abstract}

\section{Introduction}

Resource use is one of the main ecological concepts that drives animal behavior in the wild. Successful resource exploitation ensures energetic requirements for growth, survival, and reproduction are met. When resources, such as food or habitat, are limited, interspecific or intraspecific competition can lead to the use of alternative resources (Zaret and Rand 1971; Schoener 1974). Changes in resource

Responsible Editor: P. Casale.

Reviewed by: P. Chambault and T. Eguchi.

J. K. Matley

jmatley@uwindsor.ca

1 Great Lakes Institute for Environmental Research, University of Windsor, Windsor, ON N9C 1A2, Canada

2 Center for Marine and Environmental Studies, University of the Virgin Islands, St. Thomas, VI 00802, USA

3 Department of Biology, Dalhousie University, Halifax, NS B3H 4R2, Canada use due to competition may entail consumption of prey that are less energetically beneficial or more difficult to obtain (Langeland et al. 1991; Petrov et al. 2020). Alternatively, short- or long-term shifts in spatial distribution may occur to mitigate exclusion from preferred resources (Davoren et al. 2003; Papastamatiou et al. 2006). These types of interactions are likely to have implications for ecosystem dynamics and can change the functional role of species in the environment (Finstad et al. 2011; Pringle et al. 2019).

Knowledge of resource use by threatened species is particularly imperative because it enables the identification of important areas to protect (e.g., nursery areas, foraging hotspots) and help implement effective management tools (Dunbar et al. 2008). Hawksbill sea turtles (Eretmochelys imbricata) are a circum-tropical marine reptile that has drastically declined globally in the past century (Meylan and Donnelly 1999; McClenachan et al. 2006). Indeed, this species is currently listed as Endangered in the U.S. Endangered Species Act (https://www.fisheries.noaa.gov/species/ hawksbill-turtle) and Critically Endangered on the International Union for the Conservation of Nature (IUCN) Red List (https://www.iucnredlist.org/species/8005/12881238). 
Hawksbills are ecologically valuable because they act as a keystone species by consuming coral competitors, such as sponges, algae, and corallimorphs, promoting a more diverse reef ecosystem (Hill 1998; León and Bjorndal 2002; RinconDiaz et al. 2011). This species also provides economic support to humans as a major constituent of tourism (Troëng and Drews 2004). Despite their acute conservation needs and both ecological and economic values, patterns of resource use, particularly at multi-year time scales, remain understudied for this species.

During their juvenile period, which can last up to 20 years (Boulon 1994), hawksbills stay resident in coastal areas, often in the same general area for months to years (Hart et al. 2013). Early studies described coral reefs and hard-bottom structures as key foraging habitats for juvenile hawksbills (Carr et al. 1966), but recent studies have also recorded them in other habitats, such as seagrass beds/marine vegetation, lagoons, sand beds, and man-made structures of various types (Scales et al. 2011; Gorham et al. 2014; Selby et al. 2019). Habitat complexity provided by natural (e.g., coral, rocky ledges, ledges) and artificial (e.g., underwater construction) structures is a main driver shaping juvenile hawksbill habitat use, providing suitable resting areas, protection from predators, and access to food (Rincon-Diaz et al. 2011; Wood et al. 2013; Selby et al. 2019). However, in large part, these studies lack sufficient resolution to differentiate between habitat use and habitat selection.

Interactions between individuals, such as competition, have also been speculated to play a role in the distribution of hawksbills at local scales. For example, Blumenthal et al. (2009a) suggested that vertical partitioning of habitat was a potential mechanism to decrease conspecific competition and ultimately increase the carrying capacity of foraging areas. Competition for habitat appears to be a main component of distribution due to its role providing access to protected resting sites (Rincon-Diaz et al. 2011; Wood et al. 2017). Food availability also likely has bearing on competition/distribution, but this effect is convoluted in hawksbills. For example, populations have exhibited prey selectivity (Berube et al. 2012), prioritization of abundant prey items (Rincon-Diaz et al. 2011), and a mixture of both foraging strategies (León and Bjorndal 2002). Also, hawksbills have been documented feeding in unexpected habitats, such as seagrass pastures (Bjorndal and Bolten 2010) and mangrove lagoons (Gaos et al. 2012). Overall, research on competition and other intraspecific interactions, such as territoriality, is limited. The occurrence and role of these interactions, as well as their impact on population dynamics is unclear, likely varying throughout their distribution based on available resources. Although agonistic interactions have been observed in wild juvenile hawksbills (Wood et al 2017; Van Dam and Diez 2000), direct measures of competition are difficult to obtain. Explorations of spatial overlap using long-term and continuous monitoring provide a useful proxy for resource availability and possible habitat partitioning or territoriality due to competition.

In this study, we tracked the movements of juvenile hawksbills in a small Caribbean bay using a dense acoustic receiver array (up to 41 receivers in $1.5 \mathrm{~km}^{2}$ ) and transmitters equipped with (and without) pressure sensors. We quantified diel habitat selection, 2D and 3D activity space, as well as spatial partitioning to investigate resource use patterns and potential competitive interactions among juvenile hawksbills. Given the ecological effects that resource use patterns can play on hawksbill populations, understanding their space use in the context of habitat partitioning is necessary for successful management of this critically endangered species.

\section{Methods}

\section{Study area and benthic habitat}

This study was conducted in Brewers Bay and Hawksbill Cove (hereafter referred to as BBHC), adjacent coastal areas $\left(\sim 1.5 \mathrm{~km}^{2}\right)$ southwest of St. Thomas, US Virgin Islands (Fig. 1). Brewers Bay and Hawksbill Cove support juvenile populations of both hawksbill and green (Chelonia mydas) sea turtles as juvenile foraging grounds (Gehrke 2018; Levenson 2020). Bathymetry in BBHC typically descends gradually from shore to $\sim 30 \mathrm{~m}$, except along the runway of the Cyril E. King Airport, which is constructed of large dolosse (branching concrete blocks) and drops off quickly to the seafloor (Fig. 1). In addition to the artificial dolosse, benthic structure in the bay primarily consists of continuous or patchy seagrass, sand, coral reef, and rocks. Specific benthic habitat within the study area was identified from randomized drop-camera imagery collected between 2016 and 2017 ( $n=109)$ with $25 \mathrm{~m}$ resolution following protocols outlined in Smith et al. (2016) and using the CPCe 3.6 (Coral Point Count with Excel extensions) Program. Final habitat designations were grouped as coral reef $(>10 \%$ coverage), sand, seagrass ( $>10 \%$ coverage), artificial dolosse (runway), and sand with scattered coral/rock ( $\leq 10 \%$ coral, rock, or other hard structures; Fig. 1a). Bathymetry data for BBHC (Fig. 1b) were accessed from Fredericks et al. (2015) and were compiled using the submerged topographic data (250 $\mathrm{cm}$ resolution) from second-generation Experimental Advanced Airborne Research Lidar (EAARL-B).

\section{Receiver array and animal tagging}

An acoustic receiver array consisting of Vemco (now named Innovasea) VR2W-69 $\mathrm{kHz}$ receivers $(n=36-41)$ was deployed throughout the study period between 

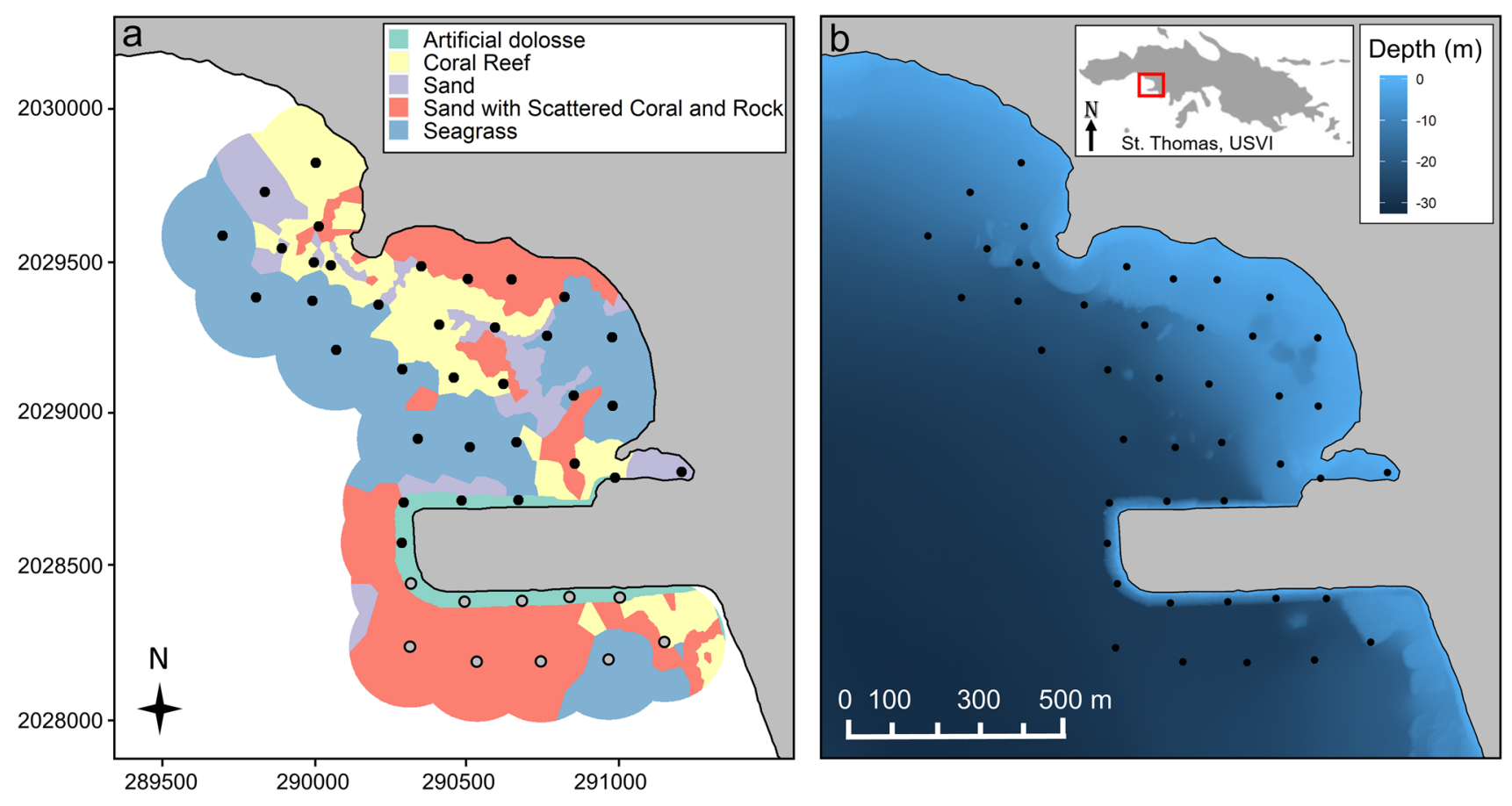

Fig. 1 Study site in Brewers Bay and Hawksbill Cove (BBHC), St. Thomas, US Virgin Islands. Acoustic receiver locations are denoted by black (Brewers Bay) and white (Hawksbill Cove) points and the

February 2015 and May 2018 (Fig. 1). The area that receivers covered was $\sim 2 \mathrm{~km}^{2}$ based on the maximum detection range for V13 and V16 transmitters-75\% detection efficiency (Matley et al. 2019). See Matley et al. $(2019,2020)$ for additional information on deployment, type of moorings used, as well as range testing information.

A total of 23 juvenile hawksbills were tagged between February 2015 and 2018 (Table 1). Eighteen of these transmitters encompassed pressure sensors allowing for depth use and 3D activity space estimation. For tagging, individuals were captured by hand on snorkel and taken back to shore for tagging and measurements (e.g., weight, curved carapace length). Vemco V13 or V16 (both with and without pressure $(0-100 \mathrm{~m} ; \pm 1.7 \mathrm{~m}$ error) sensors; tag power: 147-153 dB; nominal delay: 45-120 secs; estimated tag life: $257-3650$ days; Table 1) acoustic transmitters were attached to two posterior scutes via plastic coated wire $(2.5 \mathrm{~mm})$ and marine epoxy (Marine-Tex $\left.{ }^{\circledR}\right)$. See Matley et al. (2020) for additional tagging information. Handling and tagging of turtles were carried out with approval from the University of the Virgin Islands Animal Care and Use Committee (IRBNet ID: 11067902), and following relevant guidelines described in US study site is illustrated showing (a) habitat types within a $200 \mathrm{~m}$ buffer around each receiver and (b) bottom depth within the bay

National Marine Fisheries Service protected species permit \#15809.

\section{Data filtering}

Acoustic receivers were downloaded three times a year and false detections resulting in unknown transmitter IDs were removed. Detections were explored to remove data from transmitters that may have fallen off after tagging. For transmitters with pressure sensors $(n=18$; Table 1$)$, stagnant depth measurements were used to identify dropped tags; alternatively, prolonged detections at the same receiver were also used as a proxy to remove data from dropped tags. Individuals with low sample sizes were removed from analysis, using a minimum of 30 unique days of detections as a threshold to ensure that analysis of behavior from individuals that sparsely used the area was not incorporated. Also, only individuals with a daily residency index of $>0.5$ were analyzed to ensure space use analyses were only conducted on highly resident individuals in the study area. 
Table 1 Summary of hawksbill sea turtle tagging and detection history. Residency index (RI) was calculated as the number of unique days each individual was detected (i.e., days detected) relative to the total number of days between the first and last detection (i.e., possible days detected) of the individual

\begin{tabular}{|c|c|c|c|c|c|c|c|c|}
\hline ID & $\begin{array}{l}\text { Curved cara- } \\
\text { pace length } \\
(\mathrm{cm})\end{array}$ & Release date & Last detected & Days detected & $\begin{array}{l}\text { Possi- } \\
\text { ble days } \\
\text { detected }\end{array}$ & RI & $\begin{array}{l}\text { Day } \\
\text { No. of detections }\end{array}$ & $\begin{array}{l}\text { Night } \\
\text { No. of detections }\end{array}$ \\
\hline 45147 & 29.0 & 2016-07-30 & 2017-08-01 & 368 & 368 & 1.00 & 165,615 & 116,230 \\
\hline $1263^{\mathrm{P}}$ & 43.9 & 2017-07-23 & 2018-05-24 & 306 & 306 & 1.00 & 84,698 & 28,985 \\
\hline $1264^{\mathrm{P}}$ & 35.5 & 2017-07-23 & 2018-05-24 & 306 & 306 & 1.00 & 94,842 & 10,463 \\
\hline $1262^{\mathrm{P}}$ & 36.0 & 2017-07-30 & $2018-05-23$ & 298 & 298 & 1.00 & 53,832 & 7785 \\
\hline $15785^{\mathrm{P}}$ & 53.2 & 2017-08-06 & $2018-05-24$ & 292 & 292 & 1.00 & 150,402 & 147,055 \\
\hline $2959^{P}$ & 48.8 & 2016-07-17 & 2017-04-05 & 263 & 263 & 1.00 & 63,770 & 8613 \\
\hline $2962^{\mathrm{P}}$ & 47.0 & 2016-07-17 & 2017-04-05 & 263 & 263 & 1.00 & 84,490 & 5813 \\
\hline $1261^{\mathrm{P}}$ & 32.0 & 2017-07-30 & 2018-02-19 & 205 & 205 & 1.00 & 94,496 & 12,373 \\
\hline $1259^{\mathrm{P}}$ & 40.5 & 2017-08-05 & $2018-02-25$ & 205 & 205 & 1.00 & 82,771 & 32,366 \\
\hline $1257^{\mathrm{P}}$ & 44.5 & 2017-08-13 & 2018-03-05 & 205 & 205 & 1.00 & 180,692 & 62,612 \\
\hline $1260^{\mathrm{P}}$ & 42.2 & 2017-08-19 & 2018-03-11 & 205 & 205 & 1.00 & 46,479 & 21,148 \\
\hline $2960^{\mathrm{P}}$ & 40.6 & 2016-07-23 & 2016-12-01 & 132 & 132 & 1.00 & 47,929 & 5717 \\
\hline $15784^{\mathrm{P}}$ & 52.8 & 2018-02-04 & 2018-05-23 & 109 & 109 & 1.00 & 34,729 & 6761 \\
\hline $15783^{\mathrm{P}}$ & 29.0 & 2018-02-10 & $2018-05-25$ & 105 & 105 & 1.00 & 118,508 & 93,207 \\
\hline $2958^{P}$ & 36.0 & 2016-07-23 & 2016-08-29 & 38 & 38 & 1.00 & 3342 & 251 \\
\hline $12499^{\mathrm{P}}$ & 48.3 & 2015-04-08 & $2017-12-27$ & 987 & 995 & 0.99 & 111,359 & 3566 \\
\hline 24685 & 65.0 & $2015-05-16$ & 2017-08-15 & 811 & 823 & 0.99 & 343,522 & 229,777 \\
\hline $1258^{\mathrm{P}}$ & 40.0 & 2017-08-05 & 2018-02-25 & 202 & 205 & 0.99 & 46,930 & 2775 \\
\hline 24683 & 45.0 & $2015-02-21$ & 2016-09-09 & 554 & 567 & 0.98 & 49,566 & 8448 \\
\hline $10651^{\mathrm{P}}$ & 27.4 & 2015-02-21 & 2016-02-12 & 331 & 357 & 0.93 & 7454 & 441 \\
\hline 24455 & 28.1 & $2015-02-21$ & 2017-10-26 & 864 & 979 & 0.88 & 17,764 & 4280 \\
\hline $24684 *$ & 47.5 & $2015-02-22$ & 2015-05-12 & 31 & 80 & 0.39 & 1196 & 58 \\
\hline $2961^{\mathrm{P} *}$ & 44.1 & 2016-07-16 & 2016-08-11 & 5 & 27 & 0.19 & 708 & 174 \\
\hline Mean $( \pm S D)$ & $40.6 \pm 2.1$ & & & $336 \pm 56$ & $344 \pm 59$ & $0.99 \pm 0.01$ & $89,675 \pm 16,549$ & $38,508 \pm 13,125$ \\
\hline
\end{tabular}

The superscript 'P' in the 'ID' column indicated transmitters that had pressure/depth sensors. Two individuals (noted with an asterisk) were not analyzed because they were not resident within the study area (they are not included in mean values). IDs 24683, 24684, 24685, 12499, 15783, 15784, and 15785 were tagged with V16 transmitters whereas the rest were tagged with V13 transmitters

\section{Data analysis}

\section{D and 3D activity space estimates}

Day-and-night activity spaces in 2D were quantified using kernel density estimates (KDEs). Prior to KDE estimation, data were filtered to remove detections when individuals were at the surface or in transit towards/away from it. This was done to assist with positioning (see below) and because we were interested in space use when at the bottom of the water column since previous research (e.g., Storch et al. 2005; Blumenthal et al. 2009b; Matley et al. 2020) indicated that juvenile hawksbills in BBHC forage and rest along the seafloor. This process could only be completed for individuals tagged with depth sensors $(18 / 23)$ by removing detections that occurred shortly before and after a surface detection. We considered a surface detection as any depth shallower than $1 \mathrm{~m}$. We then removed detections $45 \mathrm{~s}$ before and $45 \mathrm{~s}$ after a surface detection to avoid incorporating movements associated with surfacing. There was limited support for hawksbills resting or foraging shallower than $1 \mathrm{~m}$ in BBHC, but to ensure we did not remove detections when individuals were using very shallow areas, if a turtle was detected $<1 \mathrm{~m}$ consecutively for more than $5 \mathrm{~min}$, these detections were kept.

The remaining detections (and non-sensor detection data) were converted to centers of activity (COAs; Simpfendorfer et al. 2002) by averaging the location of detections during $30-$ s intervals. This step was used to avoid pseudo-replication affiliated with multiple receivers detecting singular transmissions (minimum tag interval duration was 30 secs) and to help improve the resolution of positioning (Simpfendorfer et al. 2002). To better match the animal's position to the benthic habitat for individuals with depth sensors, a final filtering step was then taken to identify and remove remaining positions that were above the seafloor. This included 
removing 30-s COAs when the mean depth value was $>1 \mathrm{~m}$ shallower than the surrounding bathymetry within a $200 \mathrm{~m}$ radius (i.e., maximum expected detection range). While there is inevitably some error associated with distinguishing when individuals are on the bottom or in the water column (e.g., identifying a mid-water detection as a bottom detection due to a missed surface interval), it was likely minimal due to the filtering steps discussed above and because surface intervals were commonly detected (Matley et al. 2020).

A final positioning step was applied to transmitters with depth sensors to relocate COAs based on depth sensor values relative to the surrounding bathymetry since juvenile hawksbills were primarily using bottom/benthic habitat. Specifically, each COA's location was readjusted to a random location within a $200 \mathrm{~m}$ radius- the maximum expected detection range, where the bathymetry was within $1 \mathrm{~m}$ of the mean depth value for that COA. We chose to use a random location near the COA as opposed to the nearest location because COAs are not necessarily as accurate as other methods (Espinoza et al. 2011; Baktoft et al. 2017) and exploratory investigations showed there were spatial biases when nearest locations were used; for example, detections were placed perpendicular to shore in a linear arrangement from receivers. Furthermore, we decided to use a random location instead of a distribution of possible locations for each COA to reduce processing time, but also because our sample sizes were large enough that we deemed evident patterns would be apparent.

A random subset of 5,000 COAs was used for $2 \mathrm{D}$ and $3 \mathrm{D}$ KDE calculations for each individual and day (8:00-17:00)/ night (20:00-5:00) period. If there were fewer than 5000 observations for an individual per period, all COAs were used. For 2D activity space, the 'kernelUD' function in the adehabitatHR (Calenge 2006) R package was used to delineate $50 \%$ and $95 \%$ utilization distributions (UDs) with $10 \mathrm{~m}$ grid sizes based on a smoothing parameter $(h)$ of 75 to incorporate additional buffering for positioning error. The smoothing parameter was selected based on successive visual trials testing different values (e.g. values that were too high overestimated receiver detection ranges and overlapped too much with land and within the detection range of adjacent 'unused' receivers; values too low underestimated detection ranges and resulted in highly disjointed polygons) as suggested by Calenge (2006). Three-dimensional KDEs were also explored using the random subset of COAs and affiliated mean depth values. The 'kde' function in the $k s$ (Duong 2019) R package was used to estimate 50\% and 95\% UD volumes following Simpfendorfer et al. (2012). Threedimensional UDs were plotted by inputting KDE output into the fishtrack3d (Aspillaga et al. 2020) R package to create 3D UD meshes and topographic plots for each individual and diel period. Differences between day and night 2D and 3D UDs were tested among individuals with paired t-tests.

\section{Activity space partitioning}

Overlap of 50\% and 95\% UDs was explored between diel periods (for each individual) and among individuals (for each diel period) to explore resource partitioning. The degree of diel space overlap (DSO) between two diel periods was calculated as follows:

$\mathrm{DSO}_{a+b}=\frac{\mathrm{OA}_{a+b}}{\left(A_{a}+A_{b}\right)-\mathrm{OA}_{a+b}}$

where OA is the UD overlap area (or volume-3D) between diel period $a$ and $b$ for each individual, and $A$ is the UD area (or volume-3D) for each diel period. The output is a proportion of overlap that takes into account the size of UDs from both periods and their joint amount of overlap (Jackson 2020). When there is no overlap between UDs the DSO is 0 and for complete overlap (in both size and area), the DSO is 1. Overlap among individuals was similarly calculated; however, they were compared at a weekly level to ensure pairs of individuals were present during specific periods. Only if both individuals were present for at least 50 COAs were then included for that week. Each weekly overlap (when possible) for the individual pairings was then averaged to provide an overall shared overlap proportion for that pairing.

\section{Habitat selection}

Habitat selection of hawksbills within the study area was determined using benthic habitat maps in conjunction with detection data. Specifically, the Chesson selectivity index $(\alpha$; Chesson 1978) was used to quantify the proportion of the different habitats used by each individual relative to the area of each habitat in the study area, following:

$\alpha_{i}=\frac{\left(H_{i} / p_{i}\right)}{\sum\left(H_{i} / p_{i}\right)}$

where $H_{i}$ is the proportion of positions within habitat type $i$ and $p_{i}$ is the proportion habitat $i$ available. An index value $>1 /$ (number of category levels) represents positive selection and $<1 /$ (number of category levels) represents negative selection or avoidance. Positions used in $H_{i}$ were based on the habitat designation at 100 randomly selected coordinates within each individual's 50\% UD (core habitat use area) for both day and night periods. Available habitat encompassed the cumulative area formed by a $200 \mathrm{~m}$ buffer around each receiver within the study area (Fig. 1a). Relative depth selectivity was also calculated for each individual (with depth sensor) and time period in the same manner using the bottom depth of 100 random 50\% UD coordinates relative to the area of three bottom-depth categories $(<10$, 
$10-20, \geq 20 \mathrm{~m})$ in the study area. Therefore, the Chesson index cut-offs between positive and negative selection for habitat type and depth were $\alpha=0.20$ and $\alpha=0.33$, respectively.

To provide a comparative view between juvenile hawksbill behavior in St. Thomas (this study) and St. Croix (Selby et al. 2019), USVI, an additional approach was used to explore habitat and depth selectivity for individuals tagged with depth sensors, following methods described in Selby et al. (2019). This method employed a resource selection function binary model approach comparing the animal locations (coded as ' 1 ') with randomly selected locations in the study area (coded as ' 0 '). For each individual and diel period, we selected 100 random bathymetry-adjusted COAs to represent animal or 'presence' locations. An additional 100 random coordinates within the study area were also selected to represent the random or 'absence' locations. The random allocation of pseudo-absences in areas that are not dissimilar to occurrences can bias spatial distribution model output (Senay et al. 2013; Chambault et al. 2021). To help ensure absence locations reflected true absences (i.e., environmentally dissimilar from presence locations), absence locations were restricted to areas within the study area that fell outside a $50 \mathrm{~m}$ buffer of presence locations.

\section{Habitat modeling}

A generalized linear mixed model (GLMM; binomial distribution) tested the significance of the covariates habitat type, depth, and diel period influencing presence/absence in the study area for the resource selection function approach. The 'glmer' function in the lme4 (Bates et al. 2015) R package was used for the GLMM with animal ID as a random variable. Several candidate models were run with the lowest Akaike' information criterion (corrected for finite sample sizes; AICc; Burnham and Anderson 2002) selected as the best model. Collinearity among covariates was tested using variance inflation factors (VIF; car R package-Fox and Weisberg 2019); only VIFs < 3 (representing no collinearity) were included in candidate models. Predictive plots were created from the best model using the 'predict' function in lme 4 with $95 \%$ confidence intervals created from 100 bootstrap iterations using the 'bootMer' function. Due to the binary nature of the data, the null probability of actively selecting specific habitats or depths was 0.5 (see Selby et al. (2019) for more information).

\section{Results}

\section{D and 3D activity space estimates}

Two out of the 23 tagged juvenile hawksbills were not included in analyses due to low residency in the study area (Table 1). The remaining individuals used specific areas within BBHC and not its entirety (Fig. 2). For example, individuals either remained primarily in the northern portion of the bay, in the central portion of the bay and along the northern shore of the runway, or along the western and southern sides of the runway (Fig. 2). The mean $( \pm \mathrm{SE})$ number of detections among individuals was $89,675 \pm 16,549$ (day) and 38,508 $\pm 13,125$ (night), number of days detected was $336( \pm 56)$, and daily residency was $0.99( \pm 0.01)$ (Table 1$)$. The 2D UDs during the day (mean \pm SE $50 \%-0.090 \pm 0.009 \mathrm{~km}^{2}$, $\left.95 \%-0.392 \pm 0.035 \mathrm{~km}^{2}\right)$ were significantly larger than at night (mean \pm SE: $50 \%-0.053 \pm 0.006 \mathrm{~km}^{2}, 95 \%$ $0.235 \pm 0.026 \mathrm{~km}^{2}$ ) for both $50 \%$ (paired one-tailed $t$ test: $T_{1,20}=4.94, p<0.001$ ) and 95\% UDs (paired one-tailed $t$ test: $\left.T_{1,20}=6.53, p<0.001\right)$ (Fig. $3 \mathrm{a}$ ).

The 17 individuals analyzed with pressure-enabled sensors showed more variation in-depth use and stayed deeper during the day (mean $\pm \mathrm{SE}: 8.8 \pm 0.1 \mathrm{~m}$ ) compared to night (mean $\pm \mathrm{SE}: 7.3 \pm 0.1 \mathrm{~m})$ periods $(\mathrm{LMM}$ $F_{1,128294}=6979.8, p<0.001$; Fig. 3b). Three-dimensional UDs were correlated with 2D estimates (Pearson's correlation $p$ value $<0.01)$. The $3 \mathrm{D}$ UDs during the day (mean \pm SE $50 \%$ UD: $2.39 \mathrm{e}-4 \pm 3.34 \mathrm{e}-5 \mathrm{~km}^{3}, 95 \%$ UD: $1.83 \mathrm{e}-3 \pm 2.94 \mathrm{e}-4 \mathrm{~km}^{3}$ ) were significantly larger than at night (mean \pm SE 50\% UD: $4.23 \mathrm{e}-5 \pm 8.39 \mathrm{e}-6 \mathrm{~km}^{3}, 95 \%$ UD: $4.11 \mathrm{e}-4 \pm 8.45 \mathrm{e}-5 \mathrm{~km}^{3}$ ) for both $50 \%$ (paired onetailed $t$ test: $T_{1,15}=7.08, p<0.001$ ) and 95\% UDs (paired one-tailed $t$ test: $\left.T_{1,15}=5.38, p<0.001\right)$. These differences, including deeper habitat use, were visible when comparing $3 \mathrm{D}$ activity spaces of individuals between day and night (Fig. 4; Fig. S1).

\section{Activity space partitioning}

There was a relatively high amount of 2D overlap between day and night periods for each individual (Fig. 2). In several instances (e.g., IDs: 1261, 15,785, 1258, 1259), the UD areas at night were almost completely within the area used during the day (Fig. 2). Two-dimensional activity space overlap between day and night periods ranged from 0 to 0.68 (mean: 0.33 ) and 0.32 to 0.83 (mean: 0.52 ) for $50 \%$ and $95 \%$ UDs, respectively (Fig. 5). Three-dimensional activity space showed less overlap between day and night periods and ranged from 0 to 0.42 (mean: 0.12 ) and 
Fig. 2 Activity space of hawksbills derived from a maximum random subset of $5000 \mathrm{COAs}$ showing overlap between day (red) and night (blue) periods for each individual, as well as distribution and possible territoriality among individuals throughout the study area. 50\% and 95\% UDs are denoted by darker and lighter shading, respectively, within day and night periods. Note: following data filtering, ID 2958 did not have sufficient detections at night to be included

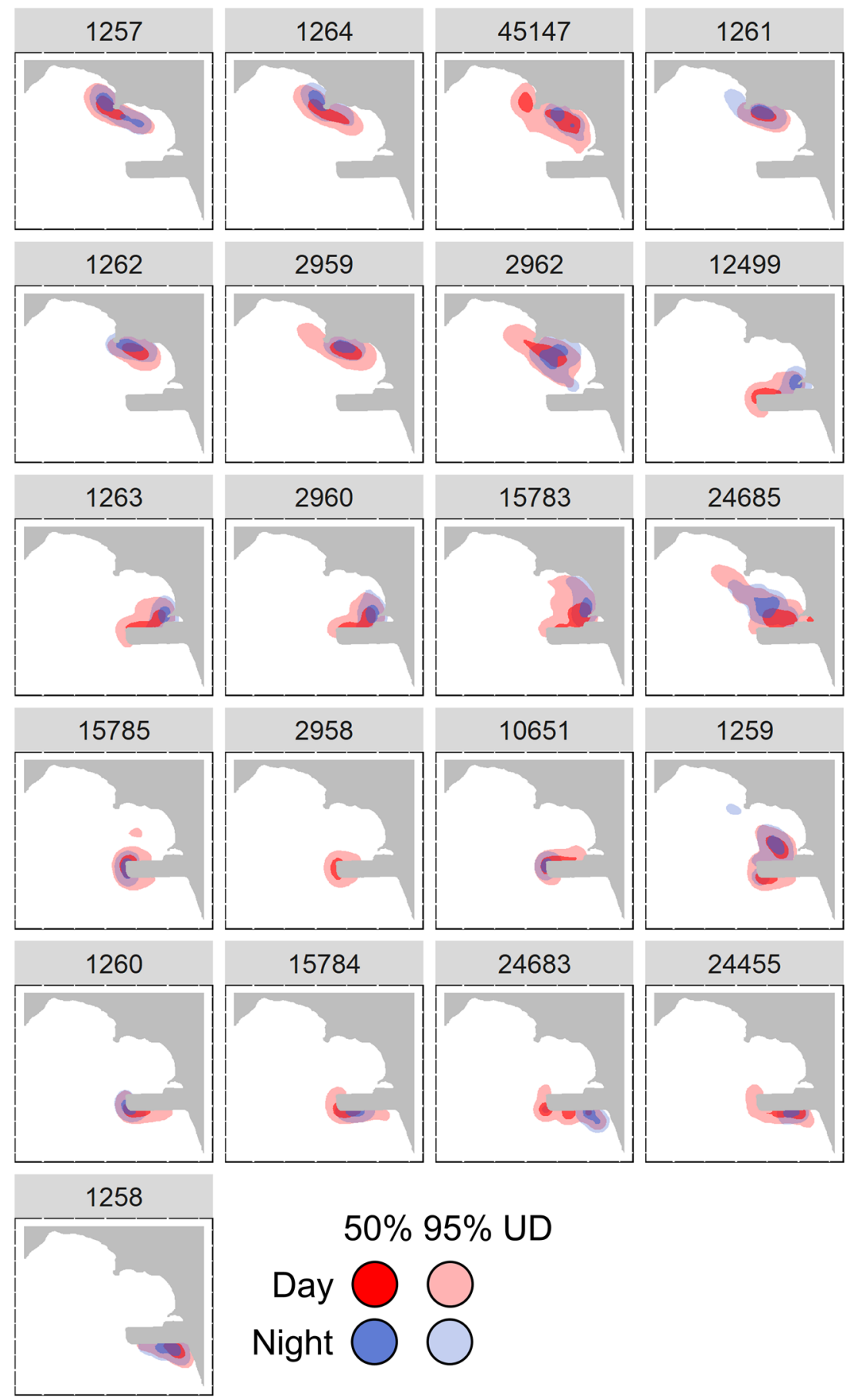

0.01 to 0.45 (mean: 0.19 ) for $50 \%$ and $95 \%$ UDs, respectively (Fig. 5).

Weekly 95\% UD 2D activity space overlap among individuals that were present within the study area during the same weekly periods had an overall mean of 0.17 (Fig. S2a) during the day, and 0.13 (Fig. S2b) during the night. Weekly 95\% UD 3D activity space overlap among individuals was limited with an overall mean of 0.07 (Fig. S2c) during the day and 0.03 (Fig. S2d) during the night.

\section{Habitat selection}

There was strong inter-individual variability in habitat preference in both day and night periods (Fig. 6a). Nevertheless, artificial dolosse (mean CI \pm SE $0.31 \pm 0.07$ ), coral reef $(0.27 \pm 0.05)$, and sand (marginally; $0.21 \pm 0.03$ ) were overall positively selected during the day, whereas coral reef (mean $\mathrm{CI} \pm \mathrm{SE} 0.36 \pm 0.05$ ) was important during the night for the majority of individuals (Fig. 6a). Waters 10-20 m 


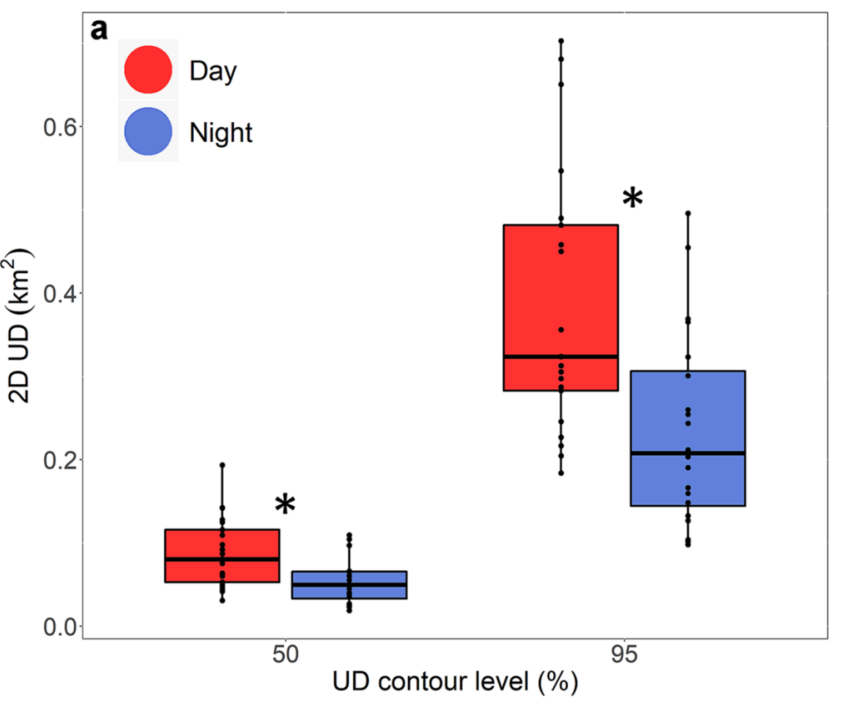

Fig. 3 Day-and-night periods for 2D activity space depicting (a) $50 \%$ and $95 \%$ UDs (black points represent areas for each individual) and (b) depth use. For boxplots, the distal end of whiskers represent the smallest and largest values no further than 1.5 times the inter-quar-

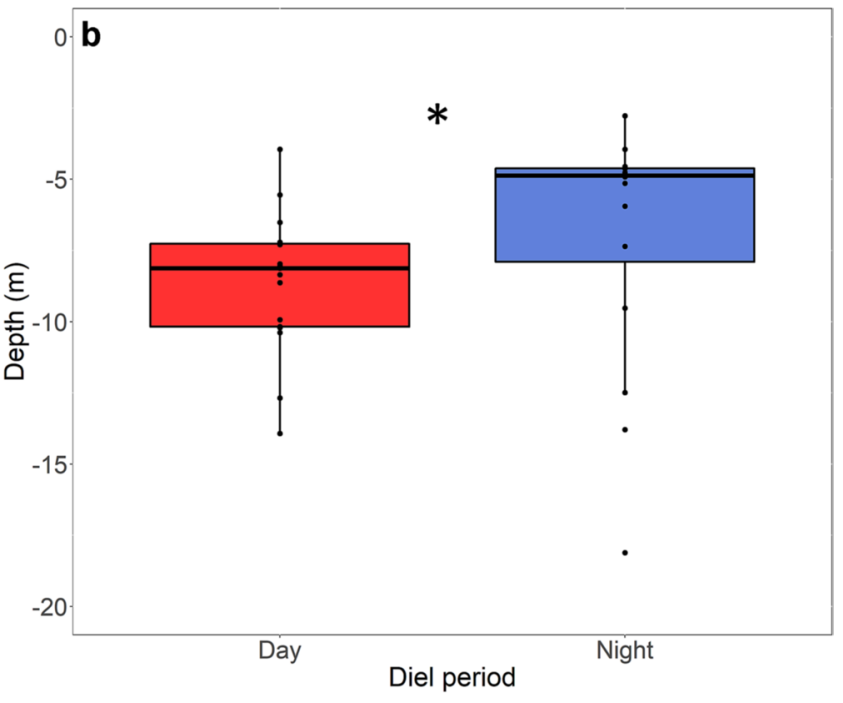

tile range, the hinges (i.e., ends of boxes) represent the 25th and 75th percentiles, and the inner horizontal line represents the median. The asterisks in (a) and (b) indicate significant differences between day and night activity space and depth estimates (see results)
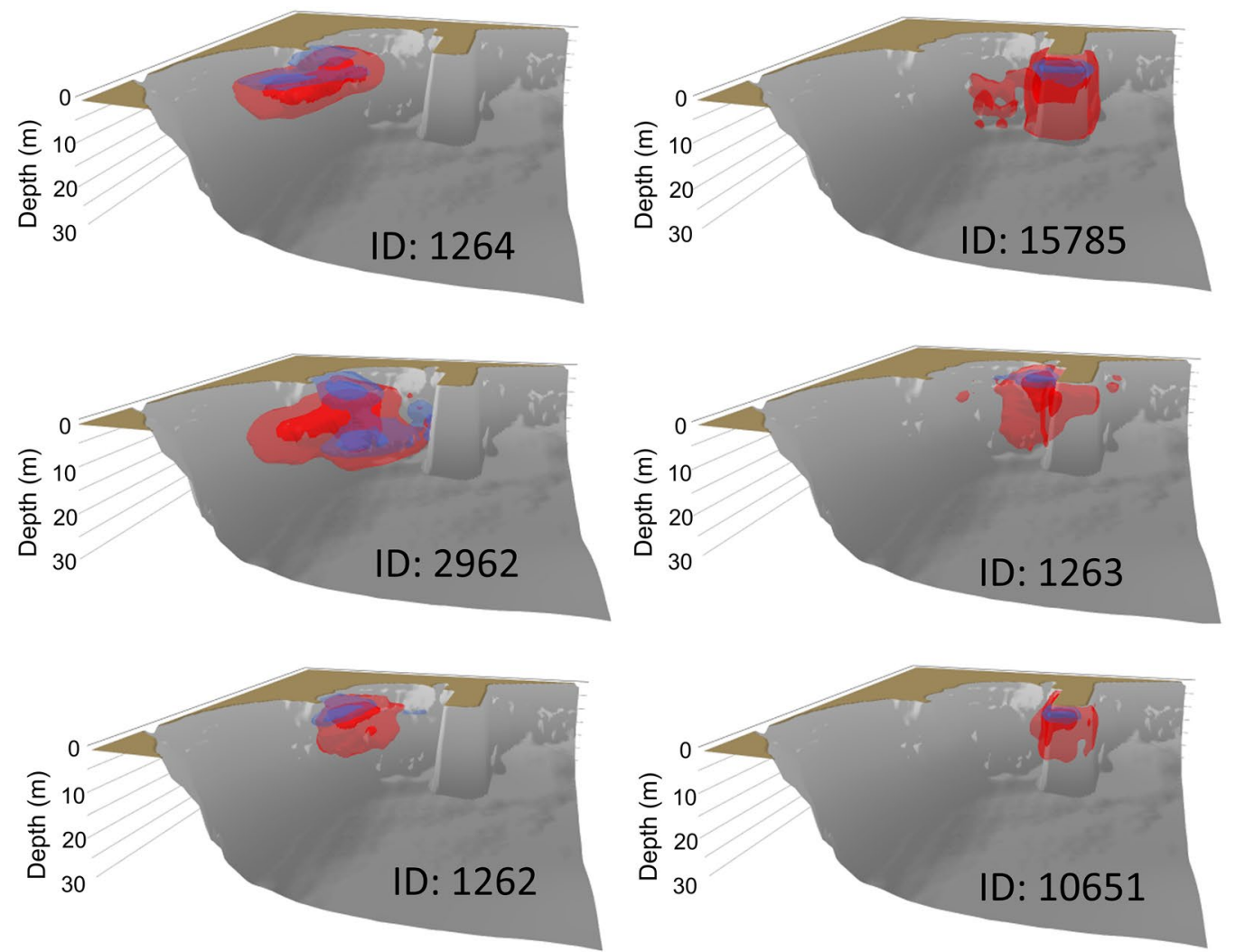

Fig. 4 Three-dimensional activity space (50\% UDs-darker shading; 95\% UDs-lighter shading) of hawksbills during day and night derived from a maximum random subset of 5000 COAs for a subdeep were overall positively selected during the day (mean $\mathrm{CI} \pm \mathrm{SE} 0.42 \pm 0.04)$ and night $(0.28 \pm 0.06$; Fig. $6 \mathrm{~b})$, while set of individuals tagged with depth sensors. 50\% and 95\% UDs are denoted by darker and lighter shading, respectively, within day and night periods. Plots can be visualized alternatively in Fig. S1

shallower depths (i.e., $<10 \mathrm{~m}$ ) were mainly selected during night (mean $\mathrm{CI} \pm \mathrm{SE}$ : $0.58 \pm 0.08$ ). Waters deeper than $20 \mathrm{~m}$ 

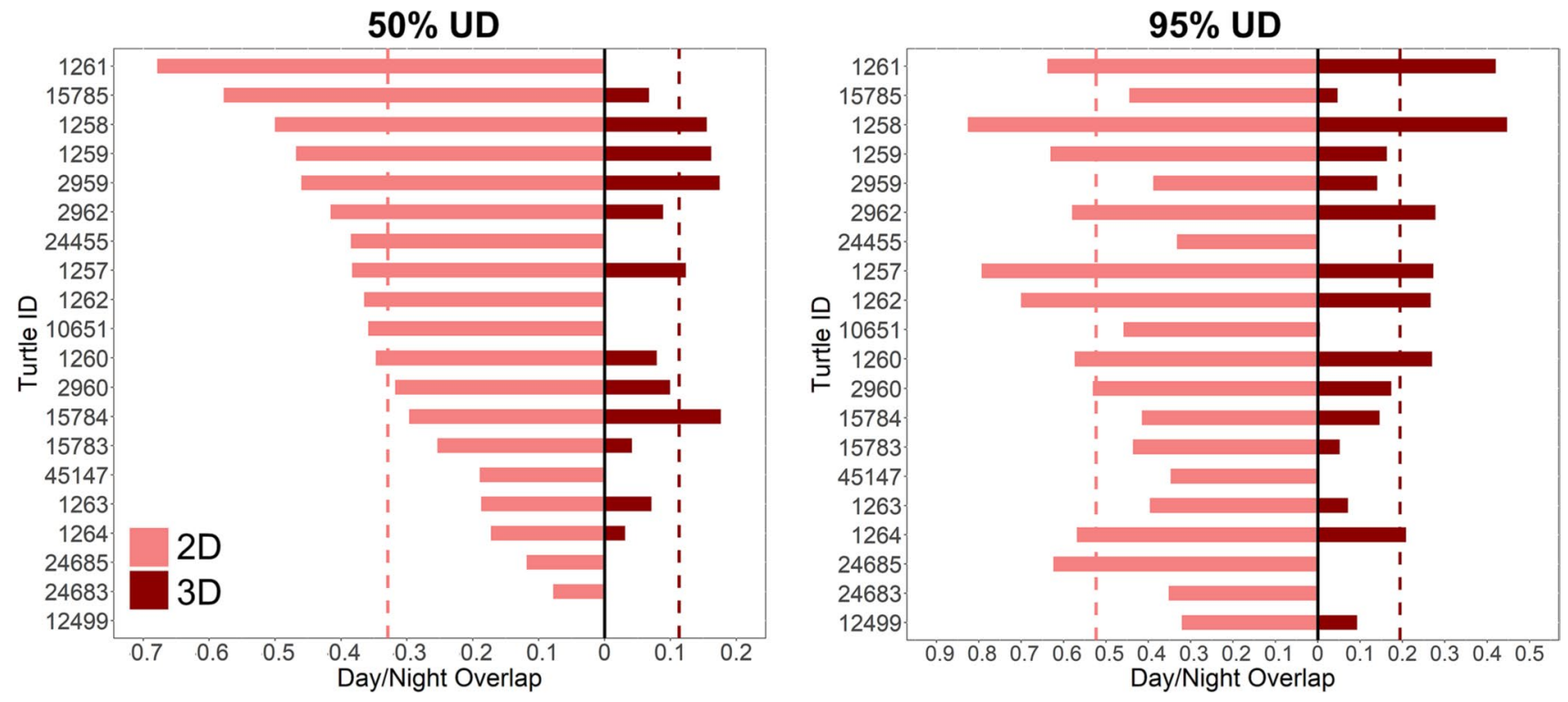

Fig. 5 Overlap of 50\% and 95\% UDs between day and night periods among individual hawksbills for 2D (pink) and 3D (red) activity spaces. Vertical dashed lines represent the mean overlap value for each overlap type and UD level

were generally avoided by all individuals throughout both diel periods (Fig. 6b). Habitat-specific selection patterns relative to depth were also demonstrated in the binomial GLMM approach using only bathymetry-adjusted positions (i.e., animals without depth sensors were not included). The best candidate model describing selection included all explanatory variables, as well as interactions between depth and habitat type, and depth and diel period (Table 2). Sand and seagrass habitat were rarely selected for in water deeper than $5 \mathrm{~m}$, and both were mainly avoided during the day at all depths (Fig. 7). Positive selection for coral reef and sand with scattered coral and rock occurred at depths shallower than $10 \mathrm{~m}$ throughout diel periods, while the artificial dolosse were regularly selected during the day up to $20 \mathrm{~m}$ deep (Fig. 7). There was considerable overlap in selection patterns between day and night periods for most habitats; however, artificial dolosse were consistently selected during the day compared to night at all depths (Fig. 7).

\section{Discussion}

\section{Activity space sizes}

Larger activity spaces during day compared to night related to periods of activity and resting, respectively (Hart et al. 2012; Wood et al. 2017). These periods are also associated with differences in dive duration in which longer dives occur at night due to fewer metabolic demands when inactive (Matley et al. 2020). It is typically incongruous to compare estimates of activity space between studies because of disparities between sample sizes, patterns of residency, receiver array configurations, and calculation techniques; however, our findings fall in line with the majority of studies that report relatively small areas of space use by immature hawksbills (Chevis et al. 2017; Wood et al. 2017) and other tropical species such as green sea turtles (Chambault et al. 2020; Griffin et al. 2020). For example, using acoustic telemetry, Carrión-Cortez et al. (2013) reported that the mean 95\% UD (KDE) of immature hawksbills in Costa Rica was $\sim 0.67 \mathrm{~km}^{2}$. Although larger space use areas have been noted in juvenile hawksbills (e.g., Nivière et al. 2018), the high residency and consistent detections in the array further supports local movements. Therefore, until maturity ( $67 \mathrm{~cm}$ CCL; Meylan et al. 2011), in which hawksbills transition from inhabiting these localized coastal areas to wider ranging oceanic movements (Meylan 1999), it is evident that $\mathrm{BBHC}$ is an important location that provides access to resources and safety during a critical and extensive period of hawksbill development.

\section{Diel activity space overlap within individuals}

The relatively high overlap in 2D activity spaces between day and night periods for each individual (e.g., 63 and 100\% of individuals had DSO $>0.30$ for 50 and $95 \%$ UDs, respectively) suggests that common areas are used within BBHC by each individual for foraging and resting. However, higherresolution tracking (e.g., Espinoza et al. 2011) is required to pinpoint exact locations of these behaviors. Nevertheless, the smaller activity spaces at night indicate that specific and fewer locations are used for resting. Exploratory analyses 
Fig. 6 Chesson selectivity index of hawksbills for the five main habitats sampled within Brewers Bay and Hawksbill Cove (a) and the three depth range categories. Index values are provided for each individual (black circles) and summarized by boxplots for day (red) and night (blue) periods. Horizontal dashed lines represent the Chesson index cut-off between positive selection and avoidance for each specific habitat or depth category. The distal end of boxplot whiskers represent the smallest and largest values no further than 1.5 times the inter-quartile range, the hinges (i.e., ends of boxes) represent the 25 th and 75 th percentiles, and the inner horizontal line represents the median
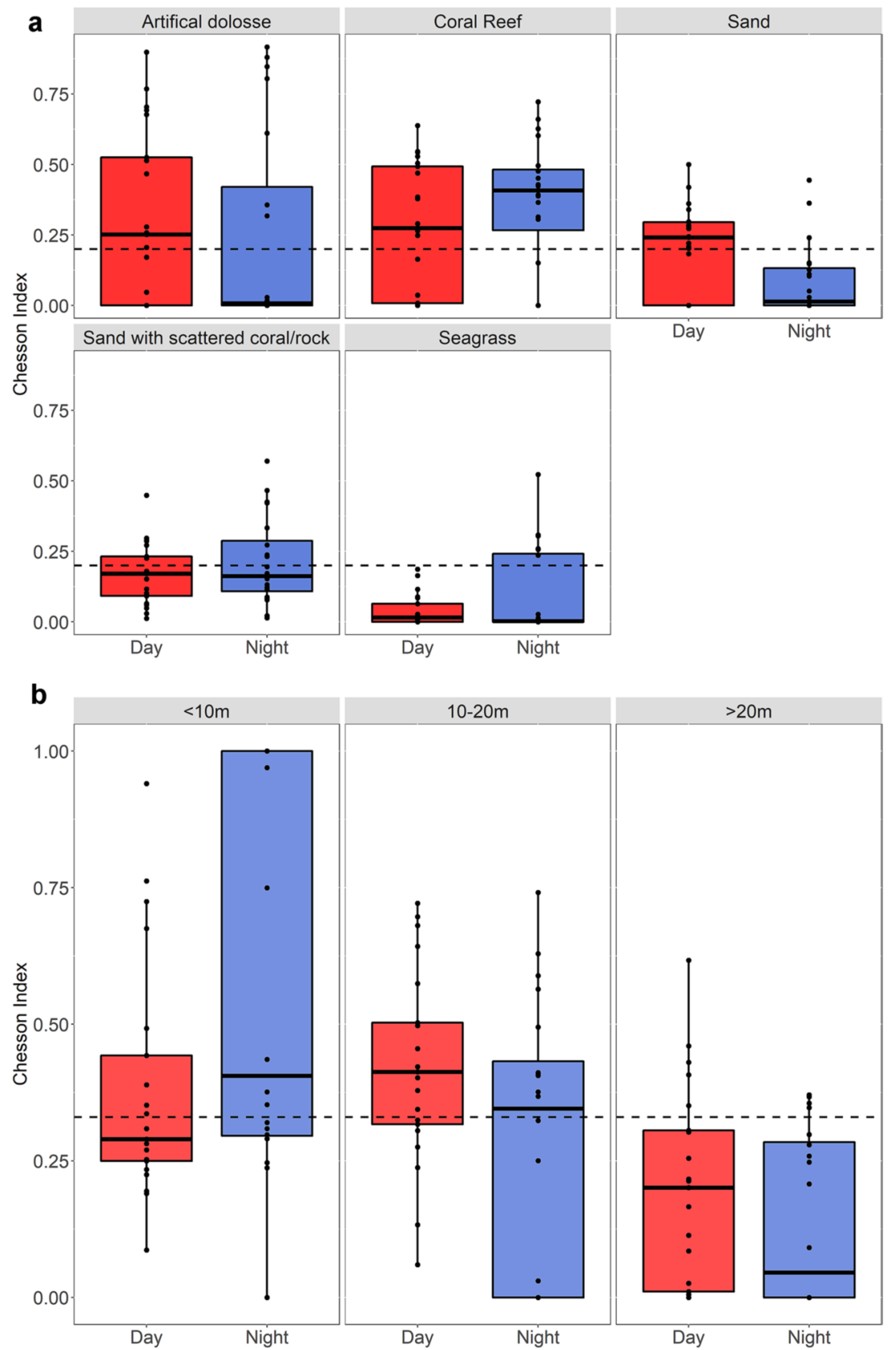

Table 2 Summary output of candidate models from generalized mixed effects models (with individual ID selected as random effect) examining the binary resource selection function of bathymetry-adjusted data points relative to habitat, diel period, and bottom depth

The optimal model based on the lowest AICc value is in bold text 

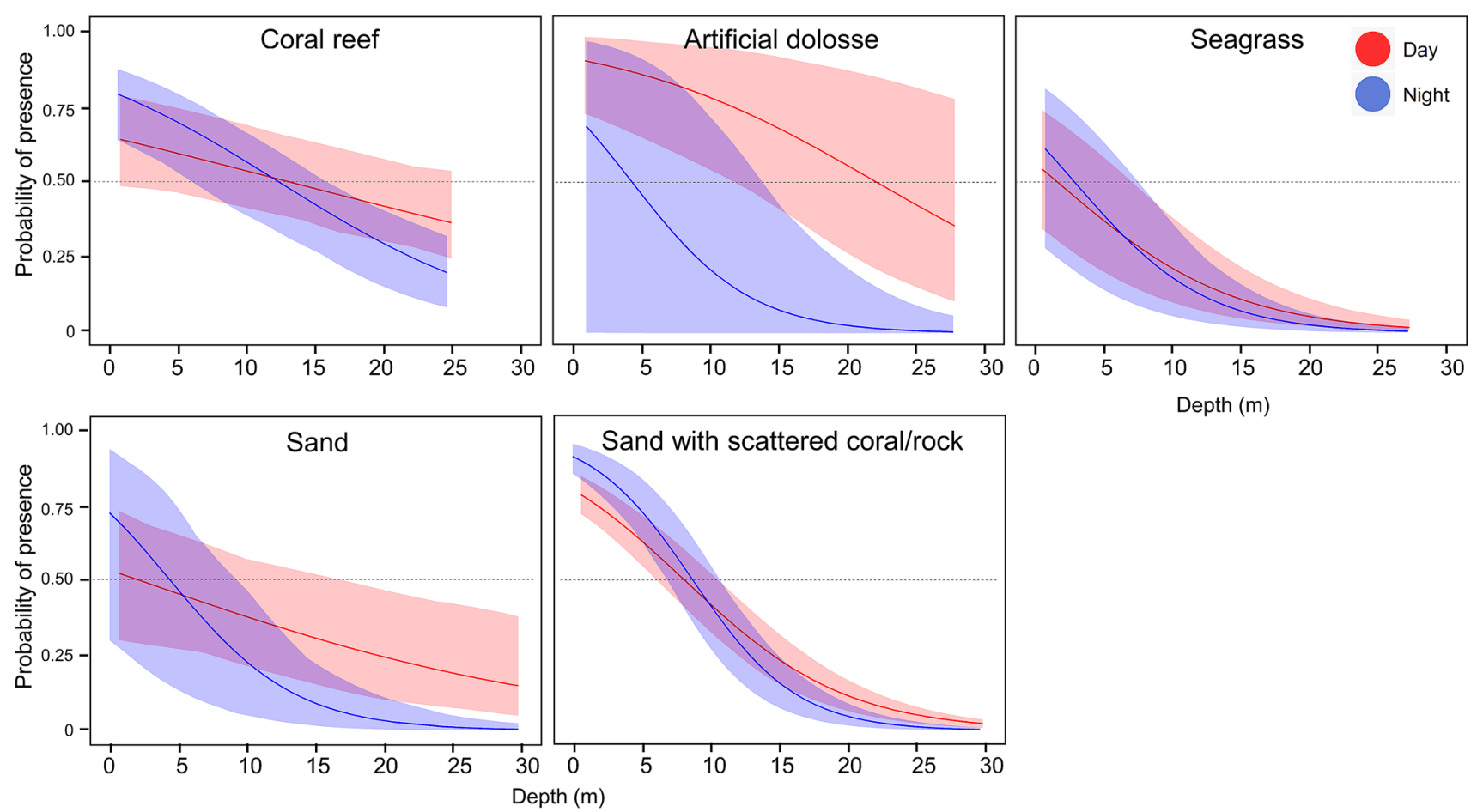

Fig. 7 Probability of detection of hawksbills across depth in the five main habitats sampled within Brewers Bay and Hawksbill Cove for day (red) and night (blue) periods. Predictions for each habitat are based on the best generalized mixed effects model examining the binary resource selection function of bathymetry-adjusted data points relative to habitat, diel period, and bottom depth. Shaded areas indicate 95\% confidence intervals around the maximum likelihood prediction and horizontal dashed lines represent the positive selection cut-off across the range of depths showed that individuals often return to the same foraging and resting locations each day cycling back and forth between diel periods. Therefore, returning to known locations that facilitate efficient foraging, resting, and protection from predators such as sharks, is likely commonplace. Other studies typically support the use of smaller areas at night compared with day by juvenile hawksbills (Chevis et al. 2017, Selby et. al. 2019) and greens (Chambault et al. 2020).

Visualization of 3D space use provided a valuable perspective for exploring vertical space use not possible with only horizontal locations. For example, Aspillaga et al. (2019) showed how activity spaces differed between spawning and non-spawning seasons in the common dentex (Dentex dentex) using a 3D approach but not for 2D-a potentially misleading result had 3D not been explored. In addition to differences in the size of 2D and 3D activity spaces, diel disparities appear to be driven primarily by the shallower depth used at night. This finding differs from many studies where juveniles dive deeper during the night (Makowski et al. 2006; Blumenthal et al. 2009b; Witt et al. 2010). It is typically more energetically efficient for sea turtles to rest in deeper waters (Minamikawa et al. 2000); however, access to resources (e.g., for resting, protection, or foraging) is also a major factor driving diel depth use patterns (Chambault et al. 2020). A possible reason for shallower depth use at night is that rugose habitat such as the artificial dolosse provide suitable assisted resting locations to help with buoyancy control when lungs are fully inflated (Houghton et al. 2003). Resting in rugose habitats, even if relatively shallow, may also reduce predation risk by providing shelter or refuge locations (Makowski et al. 2006). Ultimately, 2D activity space estimates remain biased by only providing a partial view of behavior and fail to incorporate the entire water column-highlighting the value of $3 \mathrm{D}$ approaches.

\section{Diel activity space overlap between individuals}

Hawksbills often used areas (and volumes) with limited spatial overlap between other individuals. Whether this was driven by resource partitioning or adequate resources available at scales smaller than the study area is not known. Although some individuals exhibited high levels of overlap (e.g., six and seven unique ID pairings with mean DSO $>0.5$ (2D 95\% UD) during day and night, respectively), they did not include multiple combinations of the same individuals and no size-related effects were apparent (Matley pers. obs.). This spatial partitioning spread out evenly from the 
NW portion of the bay, Black Point, to the SE corner of the runway is suggestive of territoriality. In our observations over the course of several years, very rarely were two hawksbills seen together, but two juvenile hawksbills were observed fighting (vertically attached plastron to plastron), presumably for space or food, within the runway habitat. Competitive interactions have also been observed in wild juvenile hawksbills (van Dam and Diez 2000; Blumenthal et al. 2009b; Wood et al. 2017), as well as other species of sea turtles (Schofield et al. 2007; Griffin et al. 2020). Interindividual variability and the ability to adapt to contrasting habitat types, as reported in juvenile greens in the SouthWest Indian Ocean (Chambault et al. 2020), likely also helps to buffer against competition or resource limitation. Finer-scale tracking or additional methods, such as observations via SCUBA or underwater video, would help elucidate interactions between individuals in specific areas to provide improved perspectives of social hierarchies and aggressive behavior among juveniles. Based on mark-recapture estimates, our sampling size was approximately $1 / 3$ of the population in BBHC (Jobsis pers. obs.); therefore, overlap among hawksbills may have been underestimated despite our representative sampling approach (i.e., specific areas were not targeted). Still, we believe our findings provide a valuable preliminary outlook of how juveniles exploit space and resources, suggestive of at least mild territoriality in an area of relatively high turtle density.

\section{Habitat selection}

Both selectivity methods used different approaches to explore habitat selection in BBHC but provided similar results. The positive selection for habitats, such as artificial dolosse (day) and coral reef (day/night), matched well between the two methods, not to mention the clear pattern of deeper habitats being avoided. There were some differences also; for example, sand with scattered coral and rock and sand (at night) was more important in the binary RSF method. Such differences are not surprising given the disparities between approaches, particularly that only bathymetry-adjusted data were used in the RSF method. As a result, the Chesson approach was not limited to bathymetryadjusted positions for five out of 23 individuals which may have resulted in less reliable positioning estimates. Since the RSF method used only bathymetry-adjusted data, it was likely more proficient at co-locating detections with habitat, particularly in areas where bathymetry is variable (e.g., the runway). Ultimately, a higher-resolution array is required or other method (e.g., high-resolution GPS tracking; Christiansen et al. 2017) to fully comment on the minor differences between approaches, as well as their overall effectiveness; thus, for this study, we have focused on broad trends in habitat selection.
Shallow $(<20 \mathrm{~m})$ habitats with high rugosity (coral reef, artificial dolosse, rock) were overall positively selected for. These findings are similar to those of juvenile hawksbills in nearby St. Croix, US Virgin Islands, where high-rugosity reef habitat was preferred (Selby et al. 2019). Reef habitats are typically rich in potential food items of hawksbills, which primarily consist of sponges, algae, tunicates, corallimorphs, and zoanthids (León and Bjorndal 2002; RinconDiaz et al. 2011; Carrión-Cortez et al. 2013; Cruz et al. 2016). The use of mainly coral reefs at night indicates that the structure provided is also sought for protection or camouflage from predators, shelter from the environment, or to assist in resting behavior (Blumenthal et al. 2009a; Wood et al. 2017). The artificial dolosse are a unique structure in BBHC that provide steep and highly rugose habitat that is readily used by those hawksbills living nearby, particularly during the day. During snorkel surveys, hawksbills were commonly observed resting on the surface or within the matrix of the tetrapodal structures. The sites of refuge provided by the dolosse are abundant and algal production upon their surface may support part or all of the diet of turtles using this area. However, there may be trade-offs of higherenergy food (e.g., reef-associated food and sponges) that occur more readily at the main opening of the bay. Future work on diet selection among individuals utilizing different habitats or areas in the bay, as well as the use of $3 \mathrm{D}$ accelerometers, would be an important step forward from an energetics perspective. Despite, low-rugosity sandy habitat being demonstrated as a relatively common habitat of immature hawksbills (Blumenthal et al. 2009b; Carrión-Cortez et al. 2013; Selby et al. 2019), in this study (and others), sand may have been marginally selected due to its consistent proximity to coral reefs (e.g., error associated with detection range) or as an artifact of movement between different habitats.

There was a high amount of individual variation that was relevant to habitat preferences of hawksbills. While some habitats stood out as particularly important overall (e.g., artificial dolosse — day, coral reef—day/night), each habitat showed positive selection values by at least a few individuals. The use of distinct locations within BBHC appeared to be the main attribute of this individual variation, potentially driven by territorial behavior or available resting locations. Inevitably turtles that remained in the northern portion of the bay resulted in having negative selection values for the runway because that habitat only existed in the southern portion of the study area.

\section{Conclusion}

Determining how hawksbills select resources, such as space and habitat, is relevant to evaluating and implementing appropriate conservation strategies. As a critically endangered species, there is significant impetus to 
understand the interactions among conspecifics and with the environment to inform management agencies of specific risks. This applies particularly to areas such as BBHC that support their development during potentially decadal periods. If food becomes limited within BBHC, for example, due to habitat degradation, the small and consistent areas used by individuals may need to be expanded to find food or refuge sites. Similar behavior has been observed in BBHC after Hurricanes Irma and Maria (September 2017) caused wide-spread damage on St. Thomas, in which several hawksbills left their traditional home sites during and for a short period ( week) after the hurricanes (Matley et al. 2019). These individuals used larger areas likely in response to habitat destruction or reductions in food availability - the consequences (energetic, stress, competitive, etc.) unfortunately are unknown.

The high reliance of juvenile hawksbills on habitat that provides access to food and protection reinforces similar findings from other studies and supports that habitat protection is instrumental for conservation efforts (Hamann et al. 2010; Rees et al. 2016). Like juvenile greens (Chambault et al. 2020), hawksbills show spatial resilience to seasonal (Matley et al. 2020) and extreme (Matley et al. 2019) environmental fluctuations in BBHC; however, the chronic physiological impacts may still be detrimental. Furthermore, with ongoing climate change trends in the Western Caribbean, such as ocean warming and increased coral disease (Harvell et al. 2004; Smith et al. 2016), leading to loss of preferred habitat (e.g., coral reefs; Alvarez-Filip et al. 2009; Smith et al. 2013; Hughes et al. 2018) and food sources (e.g., sponges; Edmunds et al. 2020; Gochfeld et al. 2020), resource use patterns will likely change if a critical point is reached. Therefore, gaining current knowledge of localized and long-term habitat and space use trends is important as a baseline to track and adapt to future changes in resource use.

Supplementary Information The online version contains supplementary material available at https://doi.org/10.1007/s00227-021-03912-0.

Acknowledgements We acknowledge valuable assistance from numerous students, staff, and volunteers at the University of the Virgin Islands to help collect field data, particularly J. Jossart and M. Kimble. We also thank the reviewers who provided invaluable input for this manuscript. This study was supported by VI-EPSCoR (Virgin Islands Established Program to Stimulate Competitive Research), the Lana Vento Charitable Trust, and the Baird Family Foundation. This is contribution no. \#235 to the University of the Virgin Islands' Center for Marine and Environmental Studies.

Author contributions PDJ conceived and directed research project. JKM, LKJ, STE, PDJ conducted the field work and data collection while also contributing to study design/conceptualization. JKM and NVK conducted analyses, created figures, and formatted manuscript. Original draft was prepared by JKM and LKJ, and all authors contributed to review and editing. PDJ and STE acquired funding and obtained the required permits for the project. All authors read and approved the final manuscript.

Funding This study was primarily supported by VI-EPSCoR (NSF grant no. 1355437). Additionally, the Lana Vento Charitable Trust and the Baird Family supported this research, contributing costs for acoustic receivers and transmitters.

Availability of data, code, and material The datasets generated and/or analyzed during the current study, as well as R code, are available from the corresponding author on request.

\section{Declarations}

Conflict of interest All authors declare that they have no conflict of interest.

Ethics approval Handling and tagging of turtles were carried out with approval from the University of the Virgin Islands Animal Care and Use Committee (IRBNet ID: 1106790-2), and following relevant guidelines described in US National Marine Fisheries Service protected species permit \#15809.

Open Access This article is licensed under a Creative Commons Attribution 4.0 International License, which permits use, sharing, adaptation, distribution and reproduction in any medium or format, as long as you give appropriate credit to the original author(s) and the source, provide a link to the Creative Commons licence, and indicate if changes were made. The images or other third party material in this article are included in the article's Creative Commons licence, unless indicated otherwise in a credit line to the material. If material is not included in the article's Creative Commons licence and your intended use is not permitted by statutory regulation or exceeds the permitted use, you will need to obtain permission directly from the copyright holder. To view a copy of this licence, visit http://creativecommons.org/licenses/by/4.0/.

\section{References}

Alvarez-Filip L, Dulvy NK, Gill J, Côte IM, Watkinson AR (2009) Flattening of Caribbean coral reefs: region-wide declines in architectural complexity. Proc R Soc B Biol Sci 276:3019-3025

Aspillaga E, Safi K, Hereu B, Bartumeus F (2019) Modelling the threedimensional space use of aquatic animals combining topography and Eulerian telemetry data. Methods Ecol Evol 10:1551-1557

Aspillaga E, Safi K, Hereu B, Bartumeus F (2020) fishtrack3d: Analysis of passive acoustic telemetry data in $3 \mathrm{D}$. $\mathrm{R}$ package version 1.0.0. http://github.com/aspillaga/fishtrack3d

Baktoft H, Gjelland KØ, Økland F, Thygesen UH (2017) Positioning of aquatic animals based on time-of-arrival and random walk models using YAPS (Yet Another Positioning Solver). Sci Rep 7:1-10

Bates D, Maechler M, Bolker B, Walker S (2015) Fitting linear mixedeffects models using lme4. J Stat Softw 67:1-48

Berube MD, Dunbar SG, Rützler K, Hayes WK (2012) Home range and foraging ecology of juvenile hawksbill sea turtles (Eretmochelys imbricata) on inshore reefs of Honduras. Chelonian Conserv Biol 11:33-43

Bjorndal KA, Bolten AB (2010) Hawksbill sea turtles in seagrass pastures: success in a peripheral habitat. Mar Biol 157:135-145

Blumenthal JM, Austin TJ, Bothwell JB, Broderick AC, Ebanks-Petrie G, Olynik JR, Orr MF, Solomon JL, Witt MJ, Godley BJ (2009a) 
Diving behavior and movements of juvenile hawksbill turtles Eretmochelys imbricata on a Caribbean coral reef. Coral Reefs 28:55-65

Blumenthal JM, Austin TJ, Bell CDL, Bothwell JB, Broderick AC, Ebanks-Petrie G, Gibb JA, Luke KE, Olynik JR, Orr MF, Solomon JL, Godley BJ (2009b) Ecology of Hawksbill Turtles, Eretmochelys imbricata, on a Western Caribbean Foraging Ground. Chelonian Conserv Biol 8:1-10

Boulon RH (1994) Growth rates of wild juvenile hawksbill turtles, Eretmochelys imbricata, in St. Thomas, United States Virgin Islands. Copeia 3:811-814

Burnham KP, Anderson DR (2002) Model selection and multimodel inference: a practical information-theoretic approach, 2nd edn. Springer, New York

Calenge C (2006) The package adehabitat for the R software: a tool for the analysis of space and habitat use by animals. Ecol Model 197:516-519

Carr A, Hirth H, Ogren L (1966) The ecology and migration of sea turtles, 6. The hawksbill turtle in the Caribbean Sea. Am Mus Novit 2248:1-29

Carrión-Cortez J, Canales-Cerro C, Arauz R, Riosmena-Rodríguez R (2013) Habitat use and diet of juvenile eastern Pacific hawksbill turtles (Eretmochelys imbricata) in the north Pacific coast of Costa Rica. Chelonian Conserv Biol 12:235-245

Chambault P, Dalleau M, Nicet JB, Mouquet P, Ballorain K, Jean C, Ciccione S, Bourjea J (2020) Contrasted habitats and individual plasticity drive the fine scale movements of juvenile green turtles in coastal ecosystems. Mov Ecol 8:1-15

Chambault P, Hattab T, Mouquet P, Bajjouk T, Jean C, Ballorain K, Ciccione S, Dalleau M, Bourjea J (2021) A methodological framework to predict the individual and population-level distributions from tracking data. Ecography 44:766-777

Chesson J (1978) Measuring preference in selective predation. Ecology 59:211-215

Chevis MG, Godley BJ, Lewis JP, Lewis JJ, Scales KL, Graham RT (2017) Movement patterns of juvenile hawksbill turtles (Eretmochelys imbricata) at a Caribbean coral atoll: long-term tracking using passive acoustic telemetry. Mar Ecol Prog Ser 32:309-319

Christiansen F, Esteban N, Mortimer JA, Dujon AM, Hays GC (2017) Diel and seasonal patterns in activity and home range size of green turtles on their foraging grounds revealed by extended Fastloc-GPS tracking. Mar Biol 164:10

Cruz IC, Meira VH, de Kikuchi RK, Creed JC (2016) The role of competition in the phase shift to dominance of the zoanthid Palythoa cf. variabilis on coral reefs. Mar Env Res 115:28-35

Davoren GK, Montevecchi WA, Anderson JT (2003) Distributional patterns of a marine bird and its prey: habitat selection based on prey and conspecific behaviour. Mar Ecol Prog Ser 256:229-242

Dunbar SG, Salinas L, Stevenson L (2008) In-water observations of recently released juvenile hawksbills Eretmochelys imbricata. Mar Turt Newsl 121:5-9

Duong T (2019) ks: Kernel Smoothing. R package version 1.11.6. https://CRAN.R-project.org/package $=\mathrm{ks}$

Edmunds PJ, Coblentz M, Wulff J (2020) A quarter-century of variation in sponge abundance and community structure on shallow reefs in St. John. US Virgin Islands Mar Biol 167:1-17

Espinoza M, Farrugia TJ, Webber DM, Smith F, Lowe CG (2011) Testing a new acoustic telemetry technique to quantify long-term, fine-scale movements of aquatic animals. Fish Res 108:364-371

Finstad AG, Forseth T, Jonsson B, Bellier E, Hesthagen T, Jensen AJ, Hessen DO, Foldvik A (2011) Competitive exclusion along climate gradients: energy efficiency influences the distribution of two salmonid fishes. Glob Chang Biol 17:1703-1711
Fox J, Weisberg S (2019). An \{R\} Companion to Applied Regression. Sage, Thousand Oaks, https://socialsciences.mcmaster.ca/jfox/ Books/Companion/

Fredericks X, Kranenburg CJ, Nagle DB (2015) EAARL-B Submerged Topography—Saint Thomas, U.S. Virgin Islands, 2014. U.S. Geological Survey data release. http://dx.doi.org/https://doi.org/10. 5066/F7G15XXG.

Gaos AR, Lewison RL, Yañez IL, Wallace BP, Liles MJ, Nichols WJ, Baquero A, Hasbún CR, Vasquez M, Urteaga J, Seminoff JA (2012) Shifting the life-history paradigm: discovery of novel habitat use by hawksbill turtles. Biol Lett 8:54-56

Gehrke K (2018) Home range and habitat use of juvenile green sea turtles (Chelonia mydas) in the northern Gulf of Mexico. Masters Thesis, University of the Virgin Islands pp.1-49

Gochfeld DJ, Olson JB, Chaves-Fonnegra A, Smith TB, Ennis RS, Brandt ME (2020) Impacts of hurricanes Irma and Maria on coral reef sponge communities in St. Thomas, US Virgin Islands. Estuaries Coasts 14:1-13

Gorham JC, Clark DR, Bresette MJ, Bagley DA et al (2014) Characterization of a subtropical hawksbill sea turtle (Eretmochelys imbricata) assemblage utilizing shallow water natural and artificial habitats in the Florida Keys. PLoS ONE 9:1-16

Griffin LP, Smith BJ, Cherkiss MS, Crowder AG, Pollock CG, Starr ZH, Danylchuk AJ, Hart KM (2020) Space use and relative habitat selection for immature green turtles within a Caribbean marine protected area. Anim Biotelemetry 8:1-13

Hamann M, Godfrey MH, Seminoff JA, Arthur K, Barata PC, Bjorndal KA, Bolten AB, Broderick AC, Campbell LM, Carreras C, Casale P (2010) Global research priorities for sea turtles: informing management and conservation in the 21st century. Endanger Species Res 11:245-269

Hart KM, Sartain AR, Fujisaki I, Pratt HL Jr, Morley D, Feeley MW (2012) Home range, habitat use, and migrations of hawksbill turtles tracked from Dry Tortugas National Park, Florida, USA. Mar Ecol Prog Ser 457:193-207

Hart KM, Sartain AR, Hillis-Starr ZM, Phillips B, Mayor PA, Roberson K, Pemberton RA, Allen JB, Lundgren I, Musick S (2013) Ecology of juvenile hawksbills (Eretmochelys imbricata) at Buck Island Reef National Monument, US Virgin Islands. Mar Biol 160:2567-2580

Harvell CD, Aronson RB, Baron N, Connell J, Dobson A, Ellner S, Gerber L, Kim K, Kurtis A, McCallum H, Lafferty K, McKay B, Porter JW, Pascual M, Smith G, Sutherland K, Ward J (2004) The rising tide of ocean diseases: unsolved problems and research priorities. Front Ecol Environ 2:375-382

Hill MS (1998) Spongivory on Caribbean reefs releases corals from competition with sponges. Oecologia 117:143-150

Houghton JDR, Callow MJ, Hays GC (2003) Habitat utilization by juvenile hawksbill turtles (Eretmochelys imbricata, Linnaeus, 1766) around a shallow water coral reef. J Nat Hist 37:1269-1280

Hughes TP, Anderson KD, Connolly SR, Heron SF, Kerry JT, Lough JM, Baird AH, Baum JK, Berumen ML, Bridge TC, Claar DC, Eakin CM, Gilmour JP, Graham NAJ, Harrison H, Hobbs J-PA, Hoey AS, Hoogenboom M, Lowe RJ, McCulloch MT, Pandolfi JM, Pratchett M, Schoepf V, Torda G, Wilson SK (2018) Spatial and temporal patterns of mass bleaching of corals in the Anthropocene. Science 359:80

Jackson AL (2020) Ellipse overlap: calculating the area of overlap between two ellipses. CRAN R Project. https://cran.r-project.org/ web/packages/SIBER/vignettes/Ellipse-Overlap.html. Accessed 15 July 2020

Langeland A, L’Abée-Lund JH, Jonsson B, Jonsson N (1991) Resource partitioning and niche shift in Arctic charr Salvelinus alpinus and brown trout Salmo trutta. J Anim Ecol 1:895-912 
León YM, Bjorndal KA (2002) Selective feeding in the hawksbill turtle, an important predator in coral reef ecosystems. Mar Ecol Prog Ser 245:249-258

Levenson JN (2020) Mixed stock analysis of juvenile hawksbill sea turtles (Eretmochelys imbricata) at Brewers Bay and Hawksbill Cove St Thomas, USVI. Masters Thesis, University of the Virgin Islands pp.1-32

Makowski C, Seminoff JA, Salmon M (2006) Home range and habitat use of juvenile Atlantic green turtles (Chelonia mydas L.) on shallow reef habitats in Palm Beach, Florida, USA. Mar Biol 148:1167-1179

Matley JK, Eanes S, Nemeth RS, Jobsis PD (2019) Vulnerability of sea turtles and fishes in response to two catastrophic Caribbean hurricanes. Irma and Maria Sci Rep 9:14254

Matley JK, Jossart J, Johansen L, Jobsis PD (2020) Environmental drivers of diving behavior and space-use of the endangered Caribbean juvenile hawksbill sea turtle (Eretmochelys imbricata) identified using acoustic telemetry. Mar Ecol Prog Ser 652:157-171

McClenachan L, Jackson JBC, Newman MJH (2006) Conservation implications of historic sea turtle nesting beach loss. Front Ecol Environ 4:290-296

Meylan A (1999) International Movements of Immature and Adult Hawksbill Turtles (Eretmochelys imbricata) in the Caribbean Region. Chelonian Conserv Biol 3:189-194

Meylan A, Donnelly M (1999) Status justification for listing the Hawksbill Turtle (Eretmochelys imbricata) as Critically Endangered on the 1996 IUCN Red List of Threatened Animals. Chelonian Conserv Biol 3:200-224

Meylan PA, Meylan AB, Gray JA (2011) The ecology and migrations of sea turtles. Bull Am Mus Nat Hist 357:1-71

Minamikawa S, Naito Y, Sato K, Matsuzawa Y, Bando T, Sakamoto W (2000) Maintenance of neutral buoyancy by depth selection in the loggerhead turtle Caretta caretta. J Exp Biol 203:2967-2975

Nivière M, Chambault $\mathrm{P}$, Pérez T, Etienne D, Bonola M, Martin J, Barnérias C, Védie F, Mailles J, Dumont-Dayot É, Gresser J, Hiélard G, Régis S, Lecerf N, Thieulle L, Duru M, Lefebvre F, Milet G, Guillemot B, Bildan B, de Montgolfier B, Benhalilou A, Murgale C, Maillet T, Queneherve P, Woignier T, Safi M, Le Maho Y, Petit O, Chevallier D (2018) Identification of marine key areas across the Caribbean to ensure the conservation of the critically endangered hawksbill turtle. Biol Conserv 223:170-180

Papastamatiou YP, Wetherbee BM, Lowe CG, Crow GL (2006) Distribution and diet of four species of carcharhinid shark in the Hawaiian Islands: evidence for resource partitioning and competitive exclusion. Mar Ecol Prog Ser 320:239-251

Petrov K, Spencer RJ, Malkiewicz N, Lewis J, Keitel C, Van Dyke JU (2020) Prey-switching does not protect a generalist turtle from bioenergetic consequences when its preferred food is scarce. BMC Ecol 20:1-12

Pringle RM, Kartzinel TR, Palmer TM, Thurman TJ, Fox-Dobbs K, Xu CCY, Hutchinson MC, Coverdale TC, Daskin JH, Evangelista DA, Gotanda KM, Man in 't Veld NA, Wegener JE, Kolbe JJ, Schoener TW, Spiller DA, Losos JB, BArrett RDH (2019) Predator-induced collapse of niche structure and species coexistence. Nature 570:58-64

Rees AF, Alfaro-Shigueto J, Barata PC, Bjorndal KA, Bolten AB, Bourjea J, Broderick AC, Campbell LM, Cardona L, Carreras C, Casale P (2016) Are we working towards global research priorities for management and conservation of sea turtles? Endanger Species Res 31:337-382

Rincon-Diaz MP, Diez CE, Van Dam RP, Sabat AM (2011) Effect of food availability on the abundance of juvenile hawksbill sea turtles (Eretmochelys imbricata) in inshore aggregation areas of the Culebra Archipelago, Puerto Rico. Chelonian Conserv Biol 10:213-221

Scales KL, Lewis JA, Lewis JP, Castellanos D, Godley BJ, Graham RT (2011) Insights into habitat utilisation of the hawksbill turtle, Eretmochelys imbricata (Linnaeus, 1766), using acoustic telemetry. J Exp Mar Bio Ecol 407:122-129

Schoener TW (1974) Resource partitioning in ecological communities. Science 185:27-39

Schofield G, Katselidis KA, Pantis JD, Dimopoulos P, Hays GC (2007) Female-female aggression: structure of interaction and outcome in loggerhead sea turtles. Mar Ecol Prog Ser 336:267-274

Selby T, Hart K, Smith B, Pollock C, Hillis-Starr Z, Oli M (2019) Juvenile hawksbill residency and habitat use within a Caribbean marine protected area. Endanger Species Res 40:53-64

Senay SD, Worner SP, Ikeda T (2013) Novel three-step pseudo-absence selection technique for improved species distribution modelling. PLoS ONE 8:71218

Simpfendorfer CA, Heupel MR, Hueter RE (2002) Estimation of shortterm centers of activity from an array of omnidirectional hydrophones and its use in studying animal movements. Can J Fish Aquat Sci 59:23-32

Simpfendorfer CA, Olsen EM, Heupel MR, Moland E (2012) Threedimensional kernel utilization distributions improve estimates of space use in aquatic animals. Can J Fish Aquat Sci 572:565-572

Smith TB, Brandt ME, Calnan JM, Nemeth RS, Blondeau J, Kadison E, Taylor M, Rothenberger P (2013) Convergent mortality responses of Caribbean coral species to seawater warming. Ecosphere $4: 1-40$

Smith TB, Gyory J, Brandt ME, Miller WJ, Jossart J, Nemeth RS (2016) Caribbean mesophotic coral ecosystems are unlikely climate change refugia. Glob Chang Biol 22:2756-2765

Storch S, Wilson RP, Hillis-Starr ZM, Adelung D (2005) Coldblooded divers: Temperature-dependent dive performance in the wild hawksbill turtle Eretmochelys imbricata. Mar Ecol Prog Ser 293:263-271

Troëng S, Drews C (2004) Money talks: economic aspects of marine turtle use and conservation. WWF-International, Gland, Switzerland

van Dam RP, Diez CE (2000) Remote video cameras as tools for studying turtle behaviour, pp. 168-169. In: Abreu-Grobois FA, Briseño-Dueñas R, Márquez R, Sarti-Martínez L (eds) Proceedings of the eighteenth international sea turtle symposium. NOAA Technical Memorandum NMFS-SEFSC-436. U.S. Department of Commerce

Witt MJ, McGowan A, Blumenthal JM, Broderick AC, Gore S, Wheatley D, White J, Godley BJ (2010) Inferring vertical and horizontal movements of juvenile marine turtles from time-depth recorders. Aquat Biol 8:169-177

Wood LD, Hardy R, Meylan PA, Meylan AB (2013) Characterisation of a hawksbill turtle (Eretmochelys imbricata) foraging aggregation in a high-latitude reef community in Southeastern Florida, USA. Herpetol Conserv Biol 8:258-275

Wood LD, Brunnick B, Milton SL (2017) Home range and movement patterns of subadult hawksbill sea turtles in southeast Florida. J Herpetol 51:58-67

Zaret TM, Rand AS (1971) Competition in tropical stream fishes: support for the competitive exclusion principle. Ecology 52:336-342

Publisher's Note Springer Nature remains neutral with regard to jurisdictional claims in published maps and institutional affiliations. 